\title{
Experimental investigation of the use of lignite ash for roof solar cooling
}

\author{
Eftychios Vardoulakis, Dimitris Karamanis*
}

\author{
Department of Environmental \& Natural Resources Management, University of Ioannina, Agrinio, Greece \\ * Corresponding author. Tel: +30 26410 74210, Fax: +30 26410 39576, E-mail: dkaraman@cc.uoi.gr
}

\begin{abstract}
The moisture sorption properties of fly or bottom ash and their application prospect as evaporative coolers of roof surfaces were studied. Initially, samples were characterized through techniques like elemental analysis, x-ray diffraction, thermogravimetry, reflectance measurements and water vapor adsorption isotherms. Moreover, the water adsorption properties and the associated temperature variations were determined in a specific wind tunnel with controllable environmental conditions. The adsorption isotherms were of type III indicating hydrophobic materials with low water vapor adsorption. However, all samples were capable of lowering their surface temperatures due to water evaporation and the release of the latent heat. The maximum differences in temperature increase under simulated solar irradiation between fly ash and concrete were $3.8,4.1$ and $6.4{ }^{\circ} \mathrm{C}$ for the surface, middle and bottom, respectively of $3 \mathrm{~cm}$ material thickness. The toxicity assessment of materials implication in buildings roofs was performed by radioactivity and metal leaching experiments with rain water. According to the results, mixing of fly ash with either an inert material like soil or a g reen roof material or multifunctional nanocomposites is proposed in order to minimize its environmental impact.
\end{abstract}

Keywords: Evaporative cooling, Solar cooling, Water vapor sorption, Fly ash, Lignite

\section{Introduction}

The increased temperature in the summer time of the so called "urban heat island" effect is a major energy and environmental problem of urban areas. The effect leads to the increase of electricity generation for cooling purposes and the subsequent higher pollutants emission, the chemical weathering of building materials and the increase of the discomfort and even the mortality rates. Among the mitigation measures, building integrated evaporative cooling is an alternative and sustainable way to cool the surfaces of a building or the pavement of outdoor spaces by taking advantage of the sorption properties of porous materials. Stored water or night sorbed moisture inside the pores are evaporated during the hot day and the porous surface temperature is reduced due to the release of the latent heat [1-2]. Lower surface temperatures contribute to the reduction of air temperature since the intensity of heat transfer through the cold surface is lower while the heat flow inside the building is reduced. The method of roof evaporative cooling is considered to be the most effective method for roof and indoor temperature reduction [3]. Indirect benefits associated with the installation of roof integrated porous materials for evaporative cooling include water retention in heavy rainfall, increase of the thermal insulation pollutants uptake, reduction of roof materials' degradation and carbon sequestration.

The materials' rate of water vapor sorption and the sorption capacity are the primary factors in the selection of the porous materials. However, the outdoors stability, the affordable price, the local availability and the environmental non-toxicity are secondary parameters that should also be taken into consideration in the selection of the suitable material for evaporative cooling applications and for commercial use.

Moreover, around 37 and $4.8 \mathrm{~m}$ illion of tonnes of fly and bottom ashes (FA and BA) are produced every year in Europe while more than $20 \%$ of these are produced in Greece (10 million tonnes FA per year) [4]. Fly ash is beneficially used mainly in the building industry and road construction applications such as cement or asphalt additive, autoclaved aerated concrete block, concrete admixture or aggregate and highway ice control. The average ash 
utilization rate in Europe is $47 \%$ [4]. Other applications are zeolites synthesis and hazardous waste removal, blasting grit, flowable fill material, masonry block, structural fill, grouting etc. In spite of these applications, the largest proportion of the produced fly ash is directly discharged into landfills, increasing in this way the concern of environmental pollution. Therefore, the development of alternative applications and further means to facilitate the recycling of fly ash are urgently needed. To the best of our knowledge, the potential application of fly or bottom ash as a stand-alone material or roof additives for solar cooling has not been studied yet.

In this work, the moisture sorption properties of fly and bottom ashes from the major thermoelectric power plant in Greece were determined. Prior to moisture sorption experiments, materials were characterized by x-ray diffraction, thermogravimetry, reflectance measurements and water vapor sorption isotherms. Moreover, the water sorption properties and the associated temperature reductions were determined in a secific wind tunnel with controllable environmental conditions. Finally, an initial evaluation of the environmental impact of the fly ash application was performed by radioactivity and metal leaching experiments.

\section{Methodology}

\subsection{Ash samples}

Fresh lignite by-products of fly and bottom ashes, coded ADFA and ADBA, were obtained from the lignite power plant of Agios Dimitrios (1595 MW). Fly ashes were collected in a dry state from the electrostatic precipitators of the power stations while bottom ashes were airdried at room temperature. All samples were ground by hand and sieved to a fragment size less than $200 \mu \mathrm{m}$.

\subsection{Characterization}

The major chemical constituents and trace elements of raw ashes were determined with the spectrometric methods of X-ray fluorescence (XRF) and proton-induced gamma-ray emission (PIGE) [5]. PIGE measurements were carried out at the $5.5 \mathrm{M} \mathrm{V}$ terminal voltage of the Tandem accelerator of the National Center for Scientific Research "Demokritos". Characteristic $\gamma$-rays emitted from the deexcitation of the residual nuclei following (p,p' $\gamma$ ) reactions, were used for the determination of light elements as $\mathrm{Al}, \mathrm{Si}, \mathrm{Mg}$ and $\mathrm{Na}$. XRF measurements were performed by a vertical $\mathrm{Si}(\mathrm{Li})$ detector and a ring shaped radioisotope source $\left({ }^{109} \mathrm{Cd}\right.$ or $\left.{ }^{241} \mathrm{Am}\right)$ for providing the exciting radiation [5]. Cation exchange capacity was determined by cesium sorption isotherms, traced with ${ }^{137} \mathrm{Cs}[6]$.

X-ray diffraction patterns of the prepared materials were collected on a Bruker AXS D8 Advance Bragg-Brentano geometry with $\mathrm{Cu}$ sealed tube radiation source plus a secondary beam graphite monochromator. A step of $0.02^{\circ}$ a nd a time of $6 \mathrm{~s} \mathrm{step}^{-1}$ were selected. The thermogravimetry (TG) measurements were performed on a S TA 449C (NetzchGerätebau, GmbH, Germany) thermal analyzer. The heating range was from ambient temperature up to $450{ }^{\circ} \mathrm{C}$, with a heating rate of $5{ }^{\circ} \mathrm{C} \mathrm{min}^{-1}$ under synthetic air flow rate of 40 $\mathrm{cm}^{3} \mathrm{~min}^{-1}$. The spectral reflectance of fly ash in comparison to that of a typical soil was measured using UV/VIS/NIR spectrophotometer (Varian Carry 5000 fitted with a $150 \mathrm{~mm}$ diameter, integrating sphere (Labsphere DRA 2500) that collects both specular and diffuse radiation) over the solar spectrum $(200-2500 \mathrm{~nm})$. 


\subsection{Water vapor sorption experiments}

In the moisture sorption isotherms, samples were placed in desiccators with saturated salt solutions for controlling relative humidity $(32.8,57.6,78.6$ a nd $93.6 \%)$ while temperature was air-conditionally controlled at $25^{\circ} \mathrm{C}$. Prior to measurements, samples were dried to constant mass in an air-circulated oven at $105^{\circ} \mathrm{C}$. In order to determine the sorption isotherms and kinetics, the samples were periodically weighed and the moisture content was calculated as the difference of mass measurements in different time periods and the initial dry state. The water sorption properties and the associated surface temperature reduction were conducted in a home-made wind tunnel of controllable conditions of air relative humidity, temperature and wind flow [7]. Wind flow $\left(\mathrm{m}^{3} \mathrm{~h}^{-1}\right)$, relative humidity $(\%)$ and temperature $\left({ }^{\circ} \mathrm{C}\right)$ of air inside the tunnel, weight of sample and temperatures of T-type thermocouples at the surface, middle and bottom layers of the sample cell were recorded by a CR1000 datalogger (Campbell Scientific). The solar radiation was simulated with a metal halide lamp of $400 \mathrm{~W}$ (Radium HRI-BT 400W/D).

\subsection{Toxicity assessment experiments}

The average fly ash yield of lignite burning is $10-15$ percent by weight. Therefore, the concentration of most elements (radioactive and toxic) in solid combustion wastes will be much higher than in lignite. In this frame, the concentration of radioactive isotopes and toxic metals in the ADFA sample was determined by means of $\gamma$ - and XRF spectrometry, respectively [8]. Furthermore, leaching experiments with rain water were conducted by mixing $5 \mathrm{~g}$ of fly ash with $200 \mathrm{ml}$ of rainwater under stirring for $24 \mathrm{~h}$. After vacuum filtering, leached metals was measured with XRF after preconcentration with ammonium pyrrolidine dithiocarbamate [8].

\section{Results and Discussion}

\subsection{Ash characterization}

Chemical analysis showed that $\mathrm{SiO}_{2}$ is the dominant oxide, with appreciable $\mathrm{Al}_{2} \mathrm{O}_{3}$ in both ashes (Table 1). More than $90 \%$ of the composition of the studied samples consisted of $\mathrm{Si}, \mathrm{Al}$, $\mathrm{Fe}, \mathrm{Ca}, \mathrm{Mg}, \mathrm{Na}$, and $\mathrm{K}$. Due to the high $\mathrm{CaO}$ content, the ashes were classified as Class $\mathrm{C}$.

Table 1. Concentration of major elements in the fly ash (ADFA) and bottom ash (ADBA) samples.

\begin{tabular}{cccccc}
\hline Oxide & ADFA (\%) & ADBA (\%) & Oxide (\%) & ADFA (\%) & ADBA (\%) \\
\hline $\mathrm{SiO}_{2}$ & 42.71 & 51.97 & $\mathrm{MgO}$ & 5.66 & 4.11 \\
$\mathrm{Al}_{2} \mathrm{O}_{3}$ & 16.49 & 19.14 & $\mathrm{~K}_{2} \mathrm{O}$ & 2.24 & 1.44 \\
$\mathrm{Fe}_{2} \mathrm{O}_{3}$ & 4.29 & 6.42 & $\mathrm{Na}_{2} \mathrm{O}$ & 0.88 & 0.72 \\
$\mathrm{CaO}$ & 31.31 & 14.89 & $\mathrm{TiO}_{2}$ & 0.27 & 0.45 \\
\hline
\end{tabular}

After lignite firing, the concentration of major compound of amorphous aluminosilicate glass is high in the produced ashes (up to $90 \%$ ) and there are no intense crystalline phases in the XRD patterns, especially in the region of $20-30^{\circ}$ (Fig. 1A). The minor crystalline structures are quartz $\left(\mathrm{Q}-\mathrm{SiO}_{2}\right)$, anhydrite $\left(\mathrm{An}-\mathrm{CaSO}_{4}\right)$, lime $(\mathrm{CaO})$, calcite $\left(\mathrm{C}-\mathrm{CaCO}_{3}\right)$ (mainly in the bottom ash samples), hematite $\left(\mathrm{H}-\mathrm{Fe}_{2} \mathrm{O}_{3}\right)$, maghemite $\left(\mathrm{M}-\mathrm{FeO} \cdot \mathrm{Fe}_{2} \mathrm{O}_{3}\right)$ and complexes like gehlenite $\left(\mathrm{G}_{-} \mathrm{Ca}_{2} \mathrm{Al}_{2} \mathrm{SiO}_{7}\right)$ (Fig. 1A). The cation exchange capacity of the samples was found 0.02-0.03 meq g ${ }^{-1}$, much lower than the corresponding of smectites and zeolites. The results of thermal analysis are shown in Fig. 1B. Because of the sampling of fly ash materials directly from the electrostatic filter, the moisture content of fly ash was very small and the change in 
its mass was limited up to $400^{\circ} \mathrm{C}(1 \mathrm{wt} \%)$. The bottom ash showed higher reduction in weight, with values up to $6 \%$.

The spectrophotometric reflectance data shown in Fig. 2 revealed that the tested sample exhibited a low reflectance in the entire spectrum. Moreover, the solar reflectance of the sample was calculated by weighted-averaging, using the ASTM G173-03 reference solar spectrum as the weighting function. The values of solar reflectance for each sample are shown in Table 2. In the same table, the calculated solar reflectance values for the ultra violet (UV), visible (VIS) and near infrared (NIR) part of the spectrum are also included. The reflectance of the fly ash sample was found to be higher than the reflectance of a typical soil sample. The highest difference was observed in the visible part of the spectrum since the ADFA was closer to the grey-white color than the dark-brown of the soil. Both the samples presented high absorptance in the UV and their highest reflectance in the near infrared part of the spectrum.
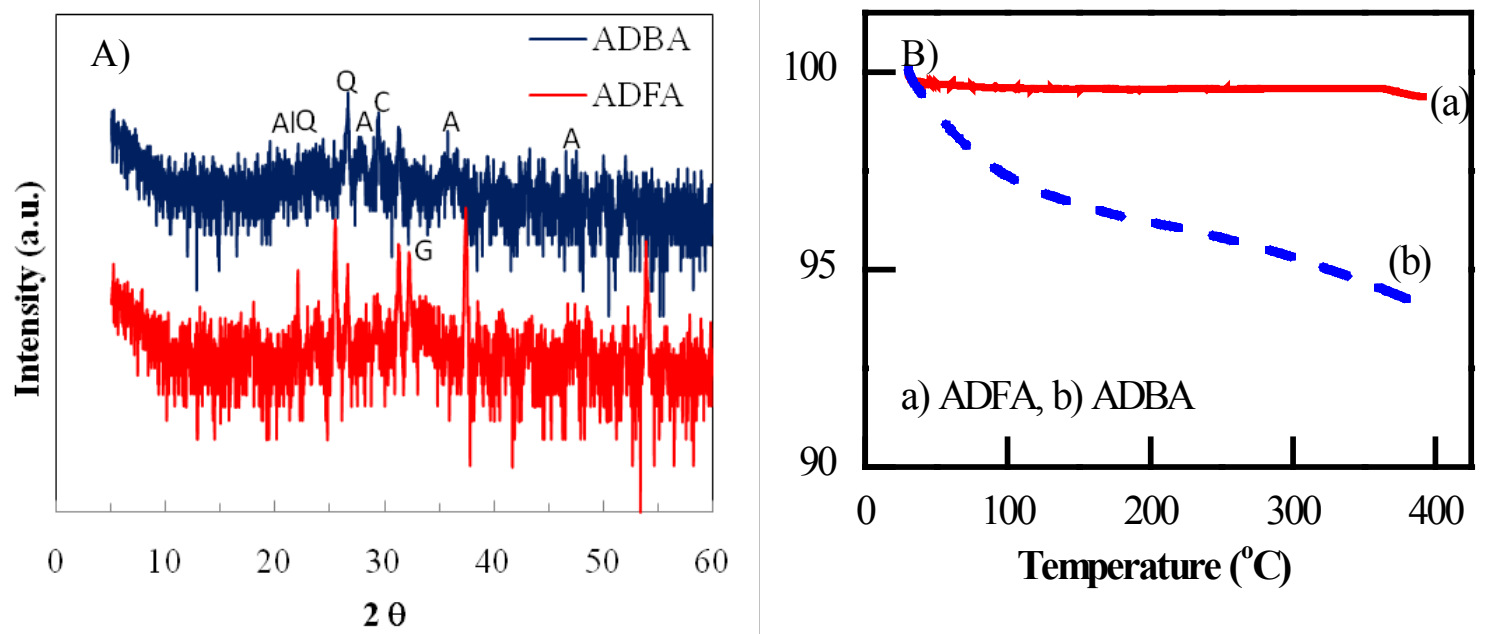

Fig. 1. A) X-ray diffraction patterns and B) TGA/DTA curves of the ash samples.

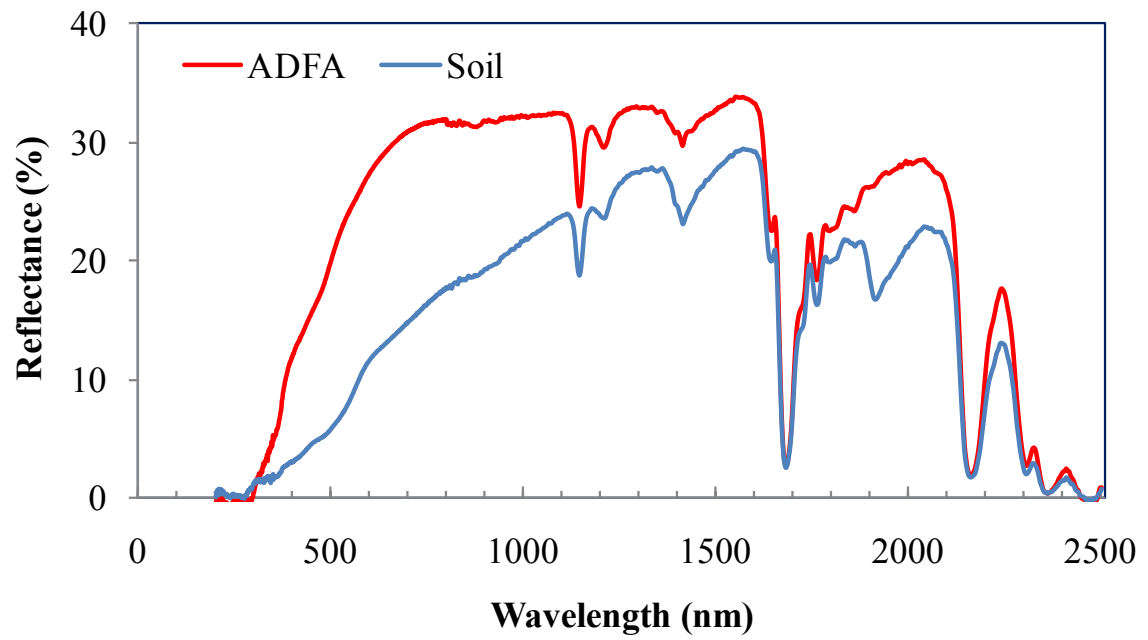

Fig. 2. Spectral reflectance of the ADFA and soil samples.

\subsection{Water vapor adsorption}

The kinetics of the two ash samples (ADFA and ADBA) and soil are shown in Fig. 3A. Upon comparison, the pseudo-second-order rate equation yielded the best results for water vapor 
adsorption on the samples. The fast rate of a few hours was responsible for more than $90 \%$ of water vapor sorption while the slow rate accounted for the rest of the adsorption.

Table 2. Solar reflectance values (SR, 280-2500 $\mathrm{nm}$ ) and solar reflectance values in the UV $(280-400 \mathrm{~nm})$, VIS $(400-700 \mathrm{~nm})$ and NIR $(700-2500 \mathrm{~nm})$ part of the spectrum of the ADFA sample and a typical soil.

\begin{tabular}{ccccc}
\hline Sample & SR (\%) & $\mathrm{SR}_{\mathrm{UV}}(\%)$ & $\mathrm{SR}_{\mathrm{VIS}}(\%)$ & $\mathrm{SR}_{\text {NIR }}(\%)$ \\
\hline ADFA & 25 & 8 & 24 & 30 \\
Soil & 12 & 2 & 9 & 19 \\
\hline
\end{tabular}
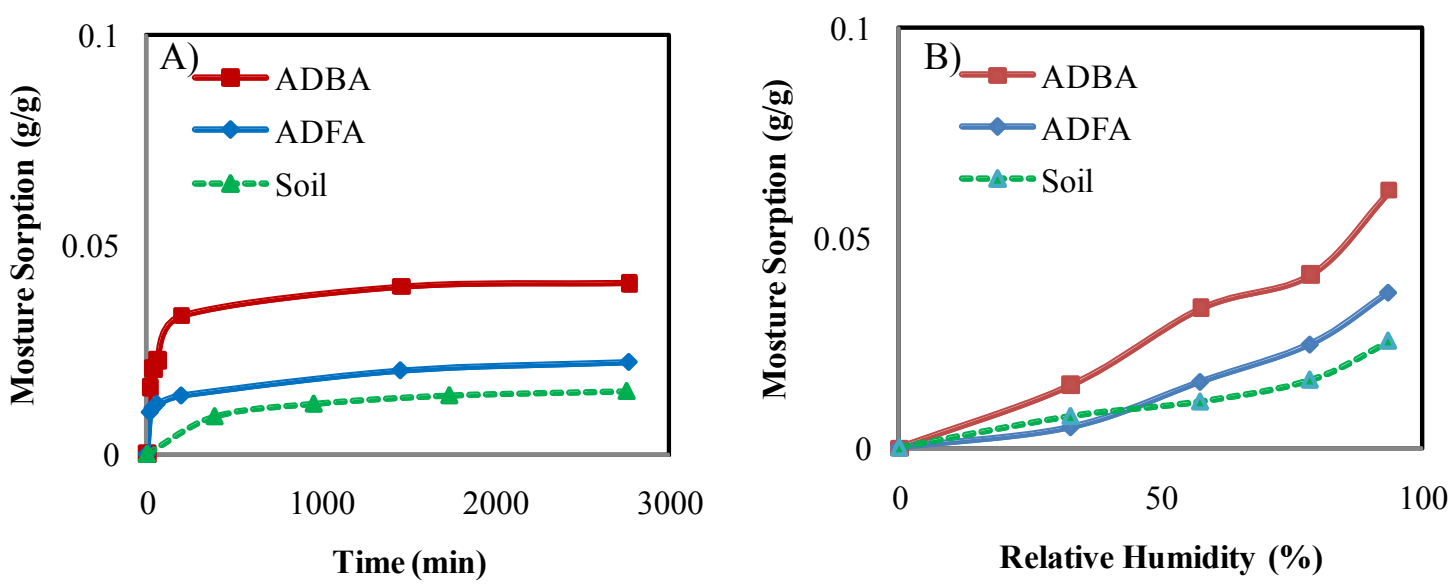

Fig. 3. Water vapor sorption A) kinetics at $60 \% \mathrm{RH}$ and B) isotherms of the ash materials and soil at $25{ }^{\circ} \mathrm{C}$.

According to the results of the kinetics experiments, water vapor adsorption in the pores of the ash samples was very low. This was further confirmed in the static measurements of sorption isotherms shown in Fig 3B. At low relative humidity, a small fraction of water was adsorbed on the samples (less than 7\%). Bottom ash possessed a higher adsorption capacity than fly ash and soil which can be attributed to adsorption sites at the unburned carbon. However, water vapor adsorption at relative humidity more than $50 \%$ (normal outdoors) was higher in both ash samples than the soil. The isotherms of the ash samples were of type III indicating the hydrophobicity of the materials with chemisorption rather than physical sorption and monolayer sorption even at high relative pressure. This result is in agreement with the hydrophobic indices, recently published for Greek fly ashes [9]. It should be mentioned that the water-holding capacities in fly ashes are much higher than those of typical soils while water sorption on fly ash is strongly affected by its organic carbon as well as by the inorganic minerals of the fly ash, which have hydrophilic properties [10].

\subsection{Evaporation cooling}

The materials were further tested in the wind tunnel under simulated solar irradiation. The radiation was provided by a metal halide lamp over the top of the wind tunnel. The incoming radiation at the test cell position was measured $50 \mathrm{~W} / \mathrm{m}^{2}$ with a portable digital solar meter. Every material test lasted for 48 hours. Initially, $3 \mathrm{ml}$ of water were sprayed on the surface of the material and left overnight. In the morning the lamp was turned on for a period of 12 hours and the cycle was repeated for one more day. All samples were capable of lowering their surface temperatures due to water evaporation and the release of the latent heat. Fig. 4 A)-C) shows the measured temperature increase for the three positions in the cyclic 
experiments with simulated solar radiation of two continuous cycles, starting from the first lamp on as the zero time. A volume cell of $3 \mathrm{~cm}$ thickness was used in all the samples while the relative humidity was raised from $60 \%$ to $80 \%$ at night with lamp off. The maximum difference of temperature increase under simulated solar irradiation was observed between the
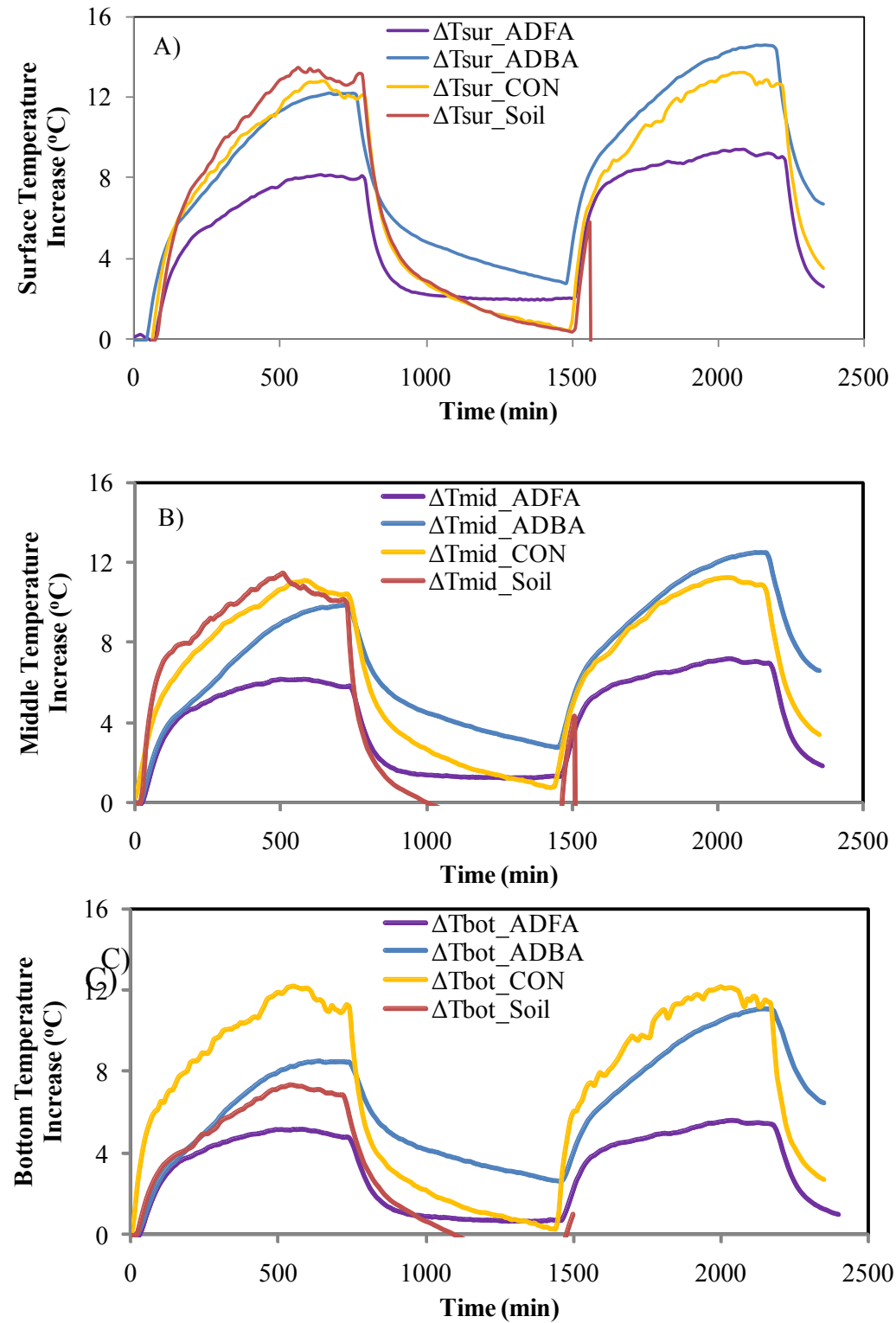

Fig. 4. Increase of the temperature at the A) surface, B) middle and C) bottom position of materials $A D F A, A D B A$, Concrete and Soil) cell due to simulated solar irradiation. (The cycle starts with the addition of $3 \mathrm{ml}$ of water in order to monitor the retention property of its material in the first cycle. 1st cycle: 0-720 min-lamp on-RH 60\%,720-1440 min-lamp off-RH 80\%; 2nd cycle: 1440-2160 min-lamp on, 2160-2400 min-lamp off).

fly ash sample and the concrete with values of $3.8,4.1$ and $6.4{ }^{\circ} \mathrm{C}$ for the surface, middle and bottom position, respectively. These results indicate the material's suitability for the proposed application of evaporative cooling and further research regarding also the performance of the fly ash samples under the more realistic conditions of open fields will be performed. 


\subsection{Toxicity assessment}

The toxicity of materials implication in buildings roofs was assessed by radioactivity and metal leaching experiments with rain water. For the proposed application, the risk from the use of fly ash is associated with three main reasons: a) outdoor exposure from the radioactive isotopes in the ash, b) internal exposure from the radioactive isotopes and toxic elements after inhalation of particulates and c) leaching of radioactive isotopes and toxic elements and contamination of water bodies. Regarding the direct exposure, the risk was estimated by the calculation of the radium equivalent activity (REA), the annual equivalent dose (AED) and the index of radiation protection (IRP) $[8,11]$. Prior to the calculation, the concentration of minor elements, toxics and radioisotopes was determined by the methods described in Ref [8]. According to the results shown in Table 3, the AED and IRP can be higher than the existing limits and therefore the fly ash sample should be mixed with an inert material in order to minimize the risk. The second way of inhalation can be eliminated by material aggregation with a binder, reducing in this way any possible wind resuspension. Regarding the third reason, leaching experiments in a $\mathrm{w}$ orst case scenario of heavy rainfall, indicated the availability of some of the metals even at the high $\mathrm{pH}$ of the Class $\mathrm{C}$ fly ash [12]. Therefore and in order to minimize the environmental impact of the use of ashes for solar cooling purposes, mixing of the fly ash with either an inert material like soil or a green roof material or multifunctional nanocomposites with high water vapor adsorption [13] is proposed.

Table 3. Concentration of minor elements and radioisotopes in the ash samples and radiotoxicity indices.

\begin{tabular}{|c|c|c|c|c|c|}
\hline $\begin{array}{c}\text { Element } \\
\text { (mg/kg) }\end{array}$ & ADFA & ADBA & $\begin{array}{l}\text { Element } \\
(\mathrm{mg} / \mathrm{kg})\end{array}$ & ADFA & ADBA \\
\hline $\mathrm{V}$ & 41.4 & BDL & $\mathrm{Rb}$ & 26.8 & 68.0 \\
\hline $\mathrm{Cr}$ & 169.9 & 138.5 & $\mathrm{Sr}$ & 292.6 & 255.1 \\
\hline Mn & 299.2 & 396.2 & $\mathrm{Y}$ & 7.9 & 16.7 \\
\hline $\mathrm{Ni}$ & 299.0 & 1824.2 & $\mathrm{Zr}$ & 129.2 & 171.8 \\
\hline $\mathrm{Cu}$ & 13.9 & 42.1 & $\mathrm{Nb}$ & 11.2 & 20.4 \\
\hline $\mathrm{Zn}$ & 38.9 & 31.5 & Mo & 3.2 & 2.4 \\
\hline Isotopes ( $\mathrm{Bq} / \mathbf{k g})$ & & & $\begin{array}{c}\text { Isotopes } \\
\text { (Bq/kg) }\end{array}$ & & \\
\hline${ }^{226} \mathrm{Ra}$ & $645 \pm 20$ & $390 \pm 12$ & ${ }^{235} \mathrm{U}$ & $30 \pm 3$ & $16 \pm 2$ \\
\hline${ }^{232} \mathrm{Th}$ & $43 \pm 2$ & $38 \pm 2$ & ${ }^{40} \mathrm{~K}$ & $222 \pm 12$ & $224 \pm 13$ \\
\hline $\begin{array}{c}\text { REA } \\
\text { (Limit } 370\end{array}$ & & & AED & & \\
\hline $\begin{array}{c}\mathrm{Bg} / \mathrm{kg}) \\
\text { IRP } \\
(\text { Limit }<1 \text { or } 6 \\
\text { and } 1 \mathrm{mSv} / \mathrm{y})\end{array}$ & 722 & 460 & (Limit $1 \mathrm{mSv} / \mathrm{y}$ ) & 0.41 & 0.26 \\
\hline
\end{tabular}

\section{Conclusions}

The extended use of air-conditioning and electricity to compensate the increased temperatures during the summer time has raised the need for the development and application of passive and efficient ways to cool down urban surfaces. In this work, fly and bottom ashes were tested as alternative applicators of the evaporative cooling principle. Cycle experiments with controllable laboratory conditions and under simulated solar irradiation, showed maximum differences between fly ash and concrete of $3.8,4.1$ and $6.4{ }^{\circ} \mathrm{C}$ for the surface, middle and bottom temperature increase, respectively. The substantial temperature reductions with the 
use of the fly ash material indicate their significant potential for cooling applications. Since, the environmental assessment revealed non negligible impact due to the high concentration of radioisotopes, further research on the treatment of fly ash for the removal of toxic elements and the increase of water vapor adsorption are in progress.

\section{Acknowledgment}

This work was supported by the John S. Latsis Public Benefit Foundation.

\section{References}

[1] Q. Meng and W. Hu, Roof cooling effect with humid porous medium, Energy and Buildings 37, 2005, pp. 1-9.

[2] S. Wanphen and K. Nagano, Experimental study of the performance of porous materials to moderate the roof surface temperature by its evaporative cooling effect, Building and Environment 44, 2009, pp. 338-351.

[3] J. Alvarado, W. Terrell, M. Johnson, Passive cooling systems for cement-based roofs, Building and Environment 44 , 2009, pp. 1869-1875.

[4] Ecoba, Production and utilisation of CCPs in $2008 \mathrm{i} \mathrm{n}$ Europe (EU 15), http://www.ecoba.com/ecobaccpprod.html, Accessed 8/10/2010.

[5] D. Karamanis, X. Aslanoglou, P.A. Assimakopoulos, N.H. Gangas, PIGE and XRF analysis of a $\mathrm{n}$ ano-composite pillared layered clay material for nuclear waste applications, Nuclear Instruments Methods B 181, 2001, pp. 616-621.

[6] D. Karamanis and P.A. Assimakopoulos, Efficiency of aluminum pillared montmorillonite on the removal of cesium and copper from aqueous solutions, Water Research 41, 2007, pp. 1897-1906.

[7] E. Vardoulakis, D. Karamanis, G. Mihalakakou, M.N. Assimakopoulos, Moisture sorption properties of modified porous clays for roof evaporative cooling applications, Proceedings of 3rd International Conference PALENC, 2010, pp. 1-11.

[8] D. Karamanis, K. Ioannides, K. Stamoulis, Environmental assessment of natural radionuclides and heavy metals in waters discharged from a lignite-fired power plant, Fuel 88, 2009, pp. 2046-2052.

[9] O.K. Karakasi, A. Moutsatsou, Surface modification of high calcium fly ash for its application in oil spill clean up, Fuel 89, 2010, pp. 3966-3970.

[10]P. Hartmann, H. Fleige, R. Horn, Physical properties of forest soils along a fly-ash deposition gradient in Northeast Germany, Geoderma 150, 2009, 188-195.

[11]G. Skordas, P. Grammelis, E. Kakaras, D. Karangelos, M. Anagnostakis, E. Hinis, Quality characteristics of Greek fly ashes and potential uses, Fuel Processing Technology $88,2007,77-85$.

[12]D. Karamanis, E. Vardoulakis, G. Antonopoulou, Ash as a Material of Passive Cooling of Buildings and Open-Air Areas, Final report of Project Funded by John S. Latsis Public Benefit Foundation, 2010 (In Greek).

[13]D. Karamanis, N. Okte, E. Vardoulakis, T. Vaimakis, Water vapor adsorption and photocatalytic pollutant degradation with $\mathrm{TiO}_{2}$-sepiolite nanocomposites, Applied Clay Science (in press). 